Dept. of Artificial Insemination and Embryo Transfer, Animal Reproduction Research Institute, Al Haram, (P. O. B. 12556), Giza, Egypt.

\title{
EFFECT OF EPIDERMAL AND INSULIN-LIKE GROWTH FACTOR-1 ON NUCLEAR MATURATION AND EMBRYO DEVELOPMENT OF BUFFALO OOCYTES IN VITRO
}

(With 5 Tables)

\author{
By \\ M.R. BADR and F.A. EL ZOHERY
}

(Received at 4/6/2011)

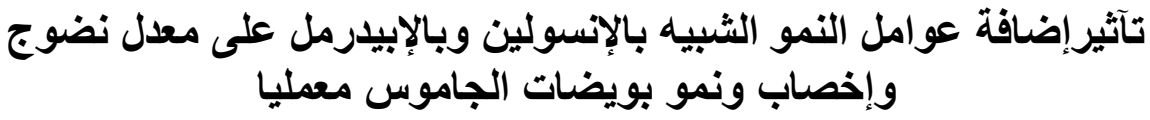
مجلى رمضان بلر ، فوزى عبل الحمبا الزهبيرى

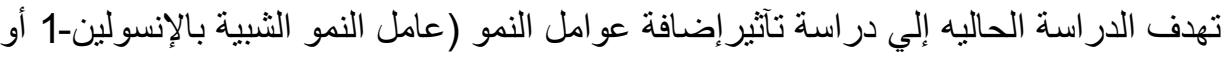

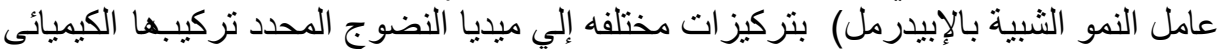

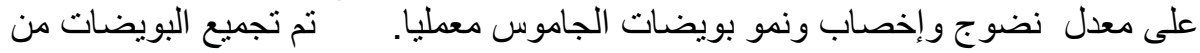

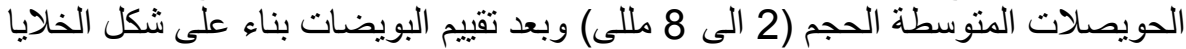

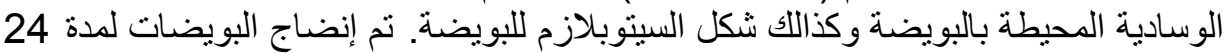

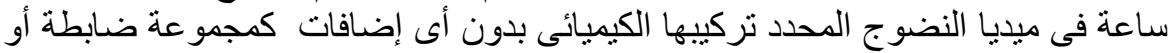

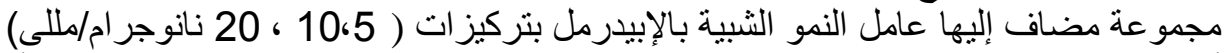

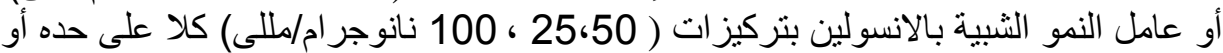

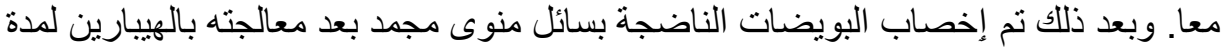

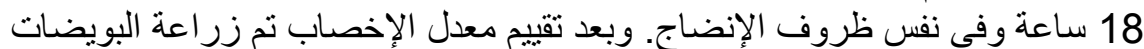

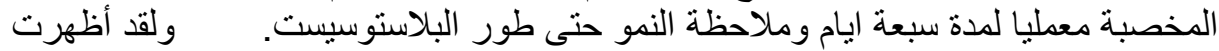

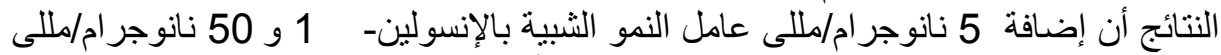

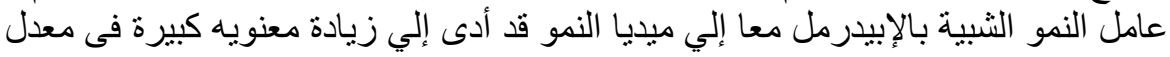

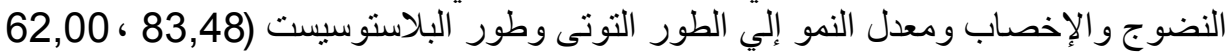

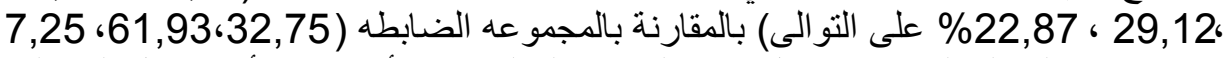

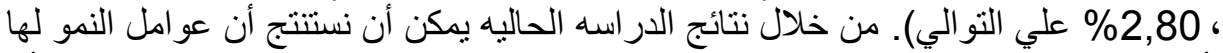

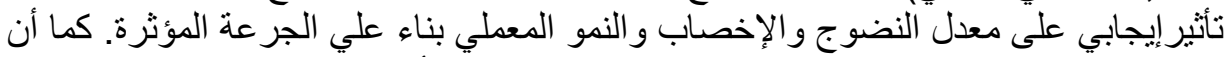

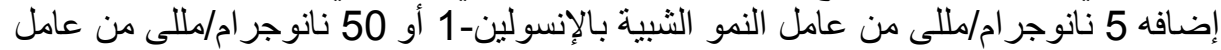

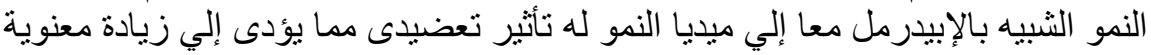




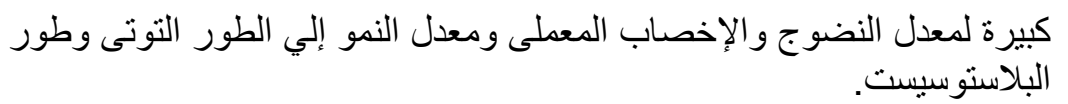

\section{SUMMARY}

The present study was aimed to investigate the possible effects of epidermal growth factor (EGF) and insulin-like growth factor 1 (IGF-1) on nuclear maturation, fertilization and embryo development in vitro of buffalo cumulus oocyte complexes (COC's). Oocytes were matured in vitro for $24 \mathrm{~h}$ in a defined SOF media with no supplements (control) or in SOF media supplemented with EGF (5, 10 and $20 \mathrm{ng} / \mathrm{ml})$, IGF-1 (25, 50, 100 $\mathrm{ng} / \mathrm{ml}$ ) or with a combination of EGF and IGF-1. After $24 \mathrm{~h}$ of in vitro maturation, oocytes were inseminated with sperm prepared in S-TALP medium supplemented with $10 \mu \mathrm{g} / \mathrm{ml}$ heparin. Embryos were evaluated for cleavage and development to the morula and blastocyst stages. The current results revealed that, addition of a combination of $5 \mathrm{ng} / \mathrm{ml}$ EGF plus $50 \mathrm{ng} / \mathrm{ml} \mathrm{IGF-1} \mathrm{to}$ the maturation medium significantly increased $(\mathrm{P}<0.01)$ the in vitro maturation, fertilization rate and embryo development to the morula and blastocyst stages (83.48 $2.27,62.00 \pm 3.19$, $29.12 \pm 4.13$ and $22.87 \pm 2.26 \%$, respectively) as compared with the control $(61.93 \pm 4.09, \quad 32.75 \pm 2.77, \quad 7.25 \pm 1.45$ and $2.80 \pm 1.42 \%$, respectively). In conclusion, the current results inferred that EGF and IGF-1 had a positive effect on buffalo ooctes maturation, fertilization and subsequent embryo development in a dose dependent trend. Supplementation of maturation medium with a combination of $5 \mathrm{ng} / \mathrm{ml}$ EGF and $50 \mathrm{ng} / \mathrm{ml}$ IGF-1 enhanced the in vitro maturation, fertilization and embryo development.

Key words: Buffalo, epidermal growth factor, insulin-like growth factor, in vitro fertilization.

\section{INTRODUCTION}

Recent studies have stressed the need for the use of chemically defined serum-free media for in vitro maturation (IVM), in vitro fertilization (IVF) and subsequent development of follicular oocytes in vitro. In general, chemically defined culture media afford development of lower blastocyst yields (Sirisathien 
and Brackett, 2003). To improve blastocyst development, several common growth factors have been added to embryo culture media as they are known to be involved in embryo development (Baştan et al., 2010). Amongst the growth factors studied as additives in such media, a combination of epidermal growth factor (EGF) and insulin-like growth factor-1 (IGF-1) appears to be an optimum combination. EGF is a mitogenic factor which has the ability to stimulate the proliferation of ovarian granulosa cells (May et al., 1987). Many reports have reported that EGF contributes to the promotion of oocyte maturation (Sanbuissho et al., 1991), germinal vesicle breakdown (GVBD), polar body formation (Das et al., 1991) and cleavage of the oocytes (Coskun et al., 1991). Moreover, several previous studies have shown that addition of IGF-1 to culture media in vitro promotes maturation of oocytes (Harper and Brackett, 1993; Rieger et al., 1995) and also affects their subsequent development in vitro (Herrler et al., 1992; Palma et al., 1997). EGF and IGF-1 in combination have been shown to act synergistically and to accelerate the cumulus expansion and the progression of meiosis (Lorenzo et al., 1994; Purohit, 2001; Sakaguchi et al., 2002). Despite their actions on early embryonic development, growth factors are not routinely included in embryo culture medium. The lack of exposure to the proper growth factor milieu may be one reason why embryos produced in vitro differ from their counterparts derived in vivo (Block et al., 2007). However, a few reports have shown that addition of IGF-1 had no effect on meiotic maturation, fertilization or embryonic development of oocytes in vitro (Grupen et al., 1997; Guler et al., 2000). Therefore, the current study was designed to evaluate the effect of EGF and IGF-1, singly or in combination, in serum-free SOF medium on in vitro nuclear maturation, fertilization and embryo development of buffalo COC's.

\section{MATERIALS and METHODS}

\section{Oocyte selection and in vitro maturation:}

Ovaries were obtained from an abattoir and were transported to the laboratory in PBS at $35^{\circ} \mathrm{C}$ within $2 \mathrm{~h}$. Oocytes were aspirated from medium follicles $(2-8 \mathrm{~mm}$ in diameter) using an 18-gauge needle attached to a $10 \mathrm{ml}$ disposable syringe. Only 
oocytes having a dense cumulus cell mass and homogeneous cytoplasm were selected. Oocytes were washed 3 times with Dulbecco's phosphate-buffered saline. The selected oocytes were cultured in $35 \mathrm{~mm}$ Petri dishes at $39^{\circ} \mathrm{C}$ under an atmosphere of $5 \% \mathrm{CO}_{2}$ in air, $95 \%$ humidity for $24 \mathrm{~h}$ for maturation. The oocytes were matured in SOF media with the addition of sodium bicarbonate, penicillin $100 \mathrm{IU} \mathrm{ml} / 1$ and streptomycin $50 \mu \mathrm{g} \mathrm{ml} / 1$ (control) or with addition of test substances (growth factors). After 24 hours, nuclear maturational status was assessed by aceto-orcien stain as described by Lorenzo et al. (1994).

\section{Sperm preparation and in vitro fertilization (IVF):}

Three straws of frozen semen were thawed in a water bath at $38^{\circ} \mathrm{C}$ for $30 \mathrm{sec}$. After thawing, the most motile spermatozoa were separated by swim up technique in sperm-TALP medium containing $6 \mathrm{mg} / \mathrm{ml}$ bovine serum albumin, for $1 \mathrm{~h}$ (Parrish et al., 1986). The uppermost layer of the medium containing the most spermatozoa was collected. The selected spermatozoa were washed twice by centrifugation at $2000 \mathrm{rpm}$ for 10 minutes. The sperm pellet was re-suspended in the fertilization TALP (FTALP) medium containing $10 \mu \mathrm{g} / \mathrm{ml}$ heparin. The prepared sperm was incubated in a $\mathrm{CO}_{2}$ incubator at $38.5^{\circ} \mathrm{C}, 5 \% \mathrm{CO}_{2}$ for 2 $\mathrm{h}$ before further use. The matured oocytes were washed with FTALP medium and the prepared sperm was added into the droplets containing matured oocytes to give a final concentration of $2 \times 10^{6}$ sperm cells $/ \mathrm{ml}$. Gametes were co-incubated in the fertilization drops under sterile mineral oil for 18 hour. At the end of gametes co-incubation, some of inseminated oocytes were freed of the attached cumulus cells, fixed in acetic acid- ethanol (1:3), stained with $1 \%$ aceto-orcein stain and examined under phase-contrast microscope (X 400) for assessing the in vitro fertilization rate according to Totey et al. (1992).

\section{In vitro culture:}

Presumptive zygotes were denuded from cumulus cells and the extra spermatozoa by gentle pipetting and transferred, into SOFaa culture medium (SOF with $1 \mathrm{mM}$ glutamine, 1\% MEM nonessential amino acids and 1\% MEM essential amino acids) and covered with mineral oil for 7 - days at $38.5{ }^{\circ} \mathrm{C}$ in an atmosphere of $5 \% \quad \mathrm{CO}_{2}$ in air with maximum humidity. The 
proportional of cleaved oocytes was recorded 48 hour after insemination and those developed to the morula and blastocyst stages were recorded at 5-7 days post-insemination according to Totey et al. (1992).

\section{Experiment 1:}

The effect of different growth factor concentrations, individually or in a combination, on nuclear maturation of buffalo oocytes were examined. Maturation medium with no extra supplement served as control. Growth factors were added to maturation medium at different concentrations, IGF-1 (25, 50, $100 \mathrm{ng} / \mathrm{ml}$, respectively) or $\operatorname{EGF}(5,10$ and $20 \mathrm{ng} / \mathrm{ml}$, respectively). Selected COC's were matured randomly in the media of different treatments. After $24 \mathrm{~h}$ the oocytes were examined to evaluate in vitro maturation rate.

\section{Experiment 2:}

COC's were matured for $24 \mathrm{~h}$ in the best concentrations of the growth factors resulted from experiment 1, singly or in combination. The matured oocytes were then fertilized and cultured in vitro to evaluate fertilization and embryo development rates in relation to each treatment.

\section{Statistical analysis:}

All data were analyzed by using Costat Computer Program, Version 3.03 copyright (1986) Cottort Software, and were compared by the least significant difference least (LSD) at $1 \%$ and $5 \%$ levels of probability.

\section{RESULTS}

Data presented in Table 1 revealed that, fortification of the maturation medium with different concentrations of IGF-1 improved the in vitro maturation rate compared to the control in a dose-dependent trend. Addition of $50 \mathrm{ng} / \mathrm{ml}$ IGF-1 to the maturation medium improved $(\mathrm{P}<0.01)$ significantly the in vitro maturation rate $(72.04 \pm 3.45 \%)$ as compared with the control $(51.48 \pm 4.55 \%)$.

Table 1: Effect of different concentrations of insulin-like growth factor 1 on the in vitro maturation rate. 


\begin{tabular}{|lc|c|c|c|}
\hline \multicolumn{2}{|c|}{ Treatment } & No. of oocytes & $\begin{array}{c}\text { No. of matured } \\
\text { oocytes }\end{array}$ & Maturation rate \\
\hline IGF-1 $\quad 25 \mathrm{ng} / \mathrm{ml}$ & 75 & 50 & $66.79 \pm 1.95^{\mathrm{a}}$ \\
\hline IGF-1 $\quad 50 \mathrm{ng} / \mathrm{ml}$ & 54 & 39 & $72.04 \pm 3.45^{\mathrm{a}}$ \\
\hline IGF-1 $\quad 100 \mathrm{ng} / \mathrm{ml}$ & 72 & 39 & $54.17 \pm 1.17^{\mathrm{b}}$ \\
\hline Control & 78 & 40 & $51.48 \pm 4.55^{\mathrm{b}}$ \\
\hline
\end{tabular}

IGF-1: insulin-like growth factor 1

Values with different superscript letters in the same columns are significantly different at least $(\mathrm{P}<0.05)$.

Results presented in Table 2 revealed that, supplementation of the maturation medium with different concentrations of EGF improved the in vitro maturation rate compared to the control in a dose-dependent trend. Addition of 5 $\mathrm{ng} / \mathrm{ml} \mathrm{EGF}$ to the maturation medium increased $(\mathrm{P}<0.01)$ significantly the in vitro maturation rate $(79.35 \pm 3.42 \%)$ as compared with the control $(64.73 \pm 2.99 \%)$.

Table 2: Effect of different concentrations of epidermal growth factor on buffalo oocytes maturation rate in vitro.

\begin{tabular}{|c|c|c|c|}
\hline Treatment & No. of oocytes & $\begin{array}{c}\text { No. of matured } \\
\text { oocytes }\end{array}$ & Maturation rate \\
\hline EGF $\quad 5 \mathrm{ng} / \mathrm{ml}$ & 83 & 66 & $79.35 \pm 3.42^{\mathrm{a}}$ \\
\hline EGF $\quad 10 \mathrm{ng} / \mathrm{ml}$ & 81 & 60 & $74.15 \pm 3.77^{\mathrm{ab}}$ \\
\hline EGF $20 \mathrm{ng} / \mathrm{ml}$ & 86 & 56 & $65.15 \pm 1.68^{\mathrm{b}}$ \\
\hline Control & 76 & 49 & $64.73 \pm 2.99^{\mathrm{b}}$ \\
\hline
\end{tabular}

EGF: Epidermal growth factor

Values with different superscript letters in the same columns are significantly different at least $(\mathrm{P}<0.05)$.

Data regarding the effect of replenishing of the maturation medium with the best concentration of the growth factors resulted from the previous experiments either singly or in combination is presented in table 3. The current results revealed that, when growth factors are combined their effects are additive.

Table 3: Effect of insulin-like growth factor 1 and /or epidermal growth factor on the in vitro maturation rate. 


\begin{tabular}{|l|c|c|c|}
\hline \multicolumn{1}{|c|}{ Treatment } & No. of oocytes & $\begin{array}{c}\text { No. of matured } \\
\text { oocytes }\end{array}$ & Maturation rate \\
\hline IGF-1 50ng/ml & 54 & 41 & $76.03 \pm 1.99^{\text {a }}$ \\
\hline EGF $5 \mathrm{ng} / \mathrm{ml}$ & 57 & 44 & $77.07 \pm 1.14^{\text {a }}$ \\
\hline $\begin{array}{l}\text { IGF-1 } 0 \mathrm{ng} / \mathrm{ml}+ \\
\text { EGF } 5 \mathrm{ng} / \mathrm{ml}\end{array}$ & 73 & 61 & $83.48 \pm 2.27^{\text {a }}$ \\
\hline Control & 71 & 44 & $61.93 \pm 4.09^{\mathrm{b}}$ \\
\hline
\end{tabular}

IGF-1: insulin-like growth factor 1

EGF: Epidermal growth factor

Values with different superscript letters in the same columns are significantly different at least $\quad(\mathrm{P}<0.05)$.

Results regarding the effect of augmentation of the maturation medium with $50 \mathrm{ng} / \mathrm{ml}$ IGF-1 and/or $5 \mathrm{ng} / \mathrm{ml}$ EGF on the in vitro fertilization rate are presented in table 4 . The current results revealed that, addition of IGF-1 and EGF in combination to the maturation medium had a positive effect on the in vitro fertilization rate $(\mathrm{P}<0.01)$ as compared with the control (62.00 \pm 3.19 vs. $32.75 \pm 2.77)$.

Table 4: Effect of insulin-like growth factor 1 and /or epidermal growth factor on the in vitro fertilization rate

\begin{tabular}{|l|c|c|c|c|}
\hline \multicolumn{1}{|c|}{ Treatment } & $\begin{array}{c}\text { No. of } \\
\text { oocytes }\end{array}$ & Penetration rate & Fertilization rate & $\begin{array}{c}\text { Abnormal } \\
\text { fertilization }\end{array}$ \\
\hline IGF-1 $50 \mathrm{ng} / \mathrm{ml}$ & 73 & $54(73.97 \pm 1.16)^{\mathrm{a}}$ & $32(45.16 \pm 3.57)^{\mathrm{b}}$ & $13(17.91 \pm 1.91)^{\mathrm{ab}}$ \\
\hline EGF $5 \mathrm{ng} / \mathrm{ml}$ & 81 & $55(67.87 \pm 2.54)^{\mathrm{a}}$ & $36(44.44 \pm 1.86)^{\mathrm{b}}$ & $13(16.86 \pm 2.80)^{\mathrm{ab}}$ \\
\hline $\begin{array}{l}\text { IGF-1 } 50 \mathrm{ng} / \mathrm{ml}+ \\
\text { EGF } 5 \mathrm{ng} / \mathrm{ml}\end{array}$ & 76 & $55(72.59 \pm 2.50)^{\mathrm{a}}$ & $47(62.00 \pm 3.19)^{\mathrm{a}}$ & $9(11.77 \pm 1.92)^{\mathrm{b}}$ \\
\hline Control & 71 & $50(70.74 \pm 2.73)^{\mathrm{a}}$ & $23(32.75 \pm 2.77)^{\mathrm{c}}$ & $16(22.26 \pm 1.73)^{\mathrm{a}}$ \\
\hline
\end{tabular}

IGF-1: insulin-like growth factor 1 EGF: Epidermal growth factor

Values with different superscript letters in the same columns are significantly different at least $(\mathrm{P}<0.05)$.

Likewise, data presented in Table 5 revealed that, combination of IGF-1 and EGF resulted in a significant increase $(\mathrm{P}<0.01)$ in the cleavage rate and embryo development to the 
morula and blastocyst stages $(46.56 \pm 3.48, \quad 29.12 \pm 4.13$ and $22.87 \pm 2.26 \%$, respectively) as compared with the control $(28.83 \pm 1.66,7.25 \pm 1.45$ and $2.80 \pm 1.42 \%$, respectively).

Table 5: Effect of insulin-like growth factor 1 and /or epidermal growth factor on the in vitro embryo development rate.

\begin{tabular}{|l|c|c|c|c|}
\hline \multicolumn{1}{|c|}{ Treatment } & $\begin{array}{c}\text { No. of } \\
\text { oocytes }\end{array}$ & Cleavage rate & Morula stage & Blastocyst stage \\
\hline IGF-1 $25 \mathrm{ng} / \mathrm{ml}$ & 61 & $24(39.81 \pm 2.65)^{\mathrm{a}}$ & $10(16.59 \pm 1.53)^{\mathrm{b}}$ & $6(9.96 \pm 1.97)^{\mathrm{b}}$ \\
\hline EGF $5 \mathrm{ng} / \mathrm{ml}$ & 70 & $29(41.85 \pm 3.09)^{\mathrm{a}}$ & $13(18.93 \pm 2.63)^{\mathrm{b}}$ & $8(11.49 \pm 1.51)^{\mathrm{b}}$ \\
\hline $\begin{array}{l}\text { IGF-1 } 50 \mathrm{ng} / \mathrm{ml}+ \\
\text { EGF } 5 \mathrm{ng} / \mathrm{ml}\end{array}$ & 75 & $35(46.56 \pm 3.48)^{\mathrm{a}}$ & $22(29.12 \pm 4.13)^{\mathrm{a}}$ & $17(22.87 \pm 2.26)^{\mathrm{a}}$ \\
\hline Control & 69 & $20(28.83 \pm 1.66)^{\mathrm{b}}$ & $5(7.25 \pm 1.45)^{\mathrm{c}}$ & $2(2.80 \pm 1.42)^{\mathrm{c}}$ \\
\hline
\end{tabular}

IGF-1: insulin-like growth factor 1

EGF: Epidermal growth factor

Values with different superscript letters in the same columns are significantly different at least $(\mathrm{P}<0.05)$.

\section{DISCUSSION}

The role of serum on meiosis resumption and oocyte maturation (Younis et al., 1989) has been demonstrated. However, several studies have recommended the use of serumfree medium for in vitro fertilization (Takagi et al., 1991) because serum quality varies from batch to batch and serum may contain materials toxic to the cell culture (Ogawa et al., 1987). It is difficult to define components already contained in the serum. The present study demonstrated that EGF and IGF-1 enhanced the in vitro maturation, fertilization and embryo development in a dose-dependent trend, but the results were marked when both EGF and IGF-1 were combined. These results were in accordance with previous studies having shown that EGF and IGF-1 have a positive effect on oocyte maturation (Kobayashi et al., 1994). Supplementation of EGF resulted in a higher proportion of nuclear maturation and normal fertilization rates compared to the control in a dose-dependent manner (Im and Park, 1995). The dose dependent effect of EGF supplementation in increasing the proportion of oocytes reaching nuclear maturation was evident only up to $20 \mathrm{ng} / \mathrm{ml}$. As pointed out by 
Harper and Brackett (1993), EGF in serum is possibly one of the undetermined components contributing to enhanced oocyte maturation. In the present study, EGF supplementation increased significantly the cleavage, and embryo development rate compared with the control. These results are in consistent with, Lonergan et al. (1996); Baştan et al. (2010) who reported that blastocyst development was significantly improved for oocytes matured in the presence of EGF.

Moreover, one growth factor that modifies embryonic physiology is insulin-like growth factor-1 (IGF-1). In the present study, IGF-1 treatment tended to increase the proportion of ooytes that matured, fertililized and developed to the blastocyst stage. Similar results were also observed in several studies (Lorenzo et al., 1996; Block et al., 2007). The effect of IGF-1 on embryo development may be partly explained by differences in culture systems since there are reports that the actions of IGF-1 to stimulate embryonic development depend upon culture conditions. IGF-1 has been shown to act on the development of bovine embryos indirectly, via granulose cells (Palma et al., 1997), the IGF-1 receptors being located in the plasma membrane of granulosa cells (Adashi et al., 1988) and that IGF-1 stimulates the proliferation and differentiation of these cells (Spicer et al., 1993). Moreover, IGF-1 can reduce the proportion of blastomeres that are apoptotic (Sirisathien and Brackett, 2003), alter the abundance of some developmentally important genes (Block et al., 2007), and increase cellular resistance to heat shock (Jousan and Hansen, 2007). Also, IGF-1 can increase development of bovine embryos to the blastocyst stage (Block and Hansen, 2007) and can increase blastocyst cell number (Sirisathien et al., 2003).

Furthermore, the proportion of oocytes that matured, fertilized or developed in vitro were significantly higher in the defined SOF medium supplemented with a combination of EGF and IGF-1 compared to their respective controls. These results were in accordance with previous studies having shown that EGF and IGF-1 have a positive effect on embryo development in various species (Lorenzo et al., 1996; Kumar and Purohit, 2004; Baştan et al., 2010). This finding indicates a synergistic action between the growth factors used and suggests that their actions are collective under in vitro conditions. 
In conclusion, the current results inferred that EGF and IGF-1 had a positive action on buffalo ooctes maturation, fertilization and subsequent embryo development in a dose dependent trend. Supplementation of maturation medium with a combination of $5 \mathrm{ng} / \mathrm{ml}$ EGF and $50 \mathrm{ng} / \mathrm{ml}$ IGF-1 enhanced the in vitro nuclear maturation, fertilization and embryo development.

\section{REFERENCES}

Adashi, E.Y.; Resnick, C.E.; Hernandez, E.R.; Svoboda, M.E. and Vanwyk, J.S. (1988): Characterization and regulation of a specific cell membrane receptor for somatomedin C/insulin-like growth factor-I in cultured rat granulosa cells. Endocrinology, 122: 194-201.

Baştan, A.; Polat, B.; Bakiacar, D.; Korkmaz, M. and Olak, A. (2010): Determination of optimal dose of EGF for bovine oocyte maturation and subsequent in vitro ertilization and culture in two media. Turk. J. Vet. Anim. Sci., 34(1): 3338.

Block, J. and Hansen, P.J. (2007): Interaction between season and culture with insulin-like growth factor-1 on survival of in vitro produced embryos following transfer to lactating dairy cows. Theriogenology, 67: 1518-29.

Block, J.; Fischer-Brown, A.E.; Rodina, T.M.; Ealy, A.D. and Hansen, P.J. (2007): The effect of in vitro treatment of bovine embryos with IGF-1on subsequent development in utero to Day 14 of gestation. Theriogenology, 68: 153-161

Coskun, S.; Sonbuissho, A.; Lin, Y.C. and Rikihisa, Y. (1991): Fertilization and subsequent developmental ability of bovine oocytes matured in medium containing epidermal growth factor (EGF). Theriogenology, 36: 485-494.

Costat Computer Program Copyright (1986): Version 3.03 copyright Cottort Software.

Das, K.; Tagatz, G.E.; Stout, L.E.; Phipps, W.R.; Hensleigh, H.C. and Leung, B.S. (1991): Direct positive effect of epidermal growth factor on the cytoplasmic maturation of mouse and human oocyte. Fertil. Steril. 55: 1000-1004.

Grupen, C.G.; Nagashima, H. and Nottle, M.B. (1997): Role of epidermal growth factor and insulin-like growth factor-1 
on procine oocyte maturation and embryonic development in vitro. Reprod. Fertil. Dev. 9: 571-575.

Guler, A.; Poulin, N.; Mermillod, P.; Terqui, M. and Cognie, Y. (2000): Effect of growth factors, EGF and IGF-1 and estradiol on in vitro maturation of sheep oocytes. Theriogenology, 54: 209-218.

Harper, K.M. and Brackett, G. (1993): Bovine blastocysts development after in vitro maturation in a defined medium with epidermal growth factor and low concentrations of gonadotropins. Biol. Reprod., 48: 409-416.

Herrler, A.; Lucas-Ham, A. and Nienann, A. (1992): Effects of insulin like growth factor-I on in vitro production of bovine embyos. Theriogenology, 37: 1213-1224.

Im, K.S. and Park, K.W. (1995): Effects of epidermal growth factor on maturation, fertilization and development of bovine follicular oocytes. Theriogenology, 44: 209-216.

Jousan, F.D. and Hansen, P.J. (2007): Insulin-like growth factorI promotes resistance of bovine preimplantation embryos to heat shock through actions independent of its antiapoptotic actions requiring PI3K signaling. Mol. Reprod. Dev., 74: 189-96.

Kobayashi, L.; Yamashita, S. and Hoshi, H. (1994): Influence of epidermal growth factor's and transforming growth factor 1 on in vitro maturation of cumulus cell enclosed bovine oocytes in a defined medium. J. Reprod. Fertil., 100: 439-446.

Kumar, D. and Purohit, G.N. (2004): Effect of epidermal and insulin-like growth factor-1 on cumulus expansion, nuclear maturation and fertilization of buffalo cumulus oocyte complexes. Vet. Arhiv., 74: 13-25.

Lonergan, P.; Carolan, C.; Van Langendonckt, A.; Donnay, I.; Khatir, H. and Mermillod, P. (1996): Role of epidermal growth factor in bovine oocyte maturation and preimplantation embryo development in vitro. Biol. Reprod., 54: 1420-1429.

Lorenzo, P.L.; Illera, M.J.; Illera, J.C. and Illera, M. (1994): Enhancement of cumulus expansion and nuclear maturation during bovine oocyte maturation in vitro by the addition of epidermal growth factors and insulin like growth factors. J. Reprod. Fertil., 101 : 697-701. 
Lorenzo, P.L.; Reboller, P.G.; Illera, M.J.; Illera, J.C.; Illera, M. and Alvarino, J.M.R. (1996): Stimulatory effect of insulinlike growth factor 1 and epidermal growth factor on the maturation of rabbit oocytes in vitro. J. Reprod. Fertil., 107: 109-117.

May, J.V.; Buck, P.A. and Schomberg, D.W. (1987): Epidermal growth factor enhances (125) iodo-follicle stimulating hormone binding by cultured porcine granulosa cells. Endocrinology, 120: 2413-2420.

Ogawa, T.; Ono, T. and Mars, R.P. (1987): The effect of serum fractions on single cell mouse embryos in vitro. J. in vitro Fert. Embryo Transfer 4: 153-158.

Palma, G.A.; Muller, M. and Brem, G. (1997): Effect of insulin like growth factor-1 (IGF-1) at high concentrations on blastocyst development of bovine embryos produced in vitro. J. Reprod. Fertil., 110: 347-353.

Parrish, J.J.; Susko-Parrish, J.L.; Leibfried-Rutledge, M.L.; Critser, E.S.; Eyestone, W.H. and First, N.L. (1986): Bovine in vitro fertilization with frozen-thawed semen. Theriogenology, 25: 591-600.

Purohit, G.N. (2001): Effect of serum free media and growth factors on IVM, IVF and Intravaginal culture of buffalo oocytes. Ph.D. Thesis, Rajasthan Agricultural University, Bikaner.

Rieger, D.; Luciano, A.M.; Modina, S.; Pocar, P.; Luria, A. and Gandolfi, F. (1995): The effect of EGF and IGF-1 on metabolism and nuclear maturation of cattle oocytes. $J$. Reprod. Fertil., Abstract.

Sakaguchi, M.; Dominko, T.; Yamauchi, N.; Leibfried-Rutledge, M.L.; Nagai, T.A. and First, N.L. (2002): Possible mechanism for acceleration of meiotic progression of bovine follicular oocytes by growth factors in vitro. Reprod., 123: 135-142.

Sanbuissho, A.; Coskun, S. and Lin, Y.C. (1991): Stimulatory action of epidermal growth factor (EGF) on in vitro bovine oocyte maturation. Assist. Reprod.Technol. Androl., 1: 143-153.

Sirisathien, S. and Brackett, B.G. (2003): TUNEL analyses of bovine blastocysts after culture with EGF and IGF-I. Mol. Reprod. Dev., 65: 51-6. 
Spicer, I.J.; Alpisar, E. and Echternkamp, S.E. (1993): Effects of insulin-like growth factor-1 and gonadotropins on bovine granulosa cell proliferation, progesterone production, estradiol production and (or) insulin-like growth factor 1 production in vitro. J. Anim. Sci., 71: 1232-1241.

Takagi, Y.; Mori, K.; Tomizawa, M.; Takahashi, T.; Sugawara, S.S. and Masaki, J. (1991): Development of bovine oocytes matured, fertilized and cultured in serum-free chemically defined medium. Theriogenology, 35:11971207.

Totey, S.M.; Singh, G.; Taneja, M.; Pawshe, C.H. and Talwar, G.P. (1992): In vitro maturation, fertilization and development of follicular oocytes from buffalo (Bubalus bubalis). Theriogenology, 39: 887-898.

Younis, A.I.; Brackett, B.G. and Fayer-Hosken, R.A. (1989): Influence of serum and hormones on bovine oocyte maturation and fertilization in vitro. Gamete Res., 23: 189-201. 